\title{
Bacteria and Mold Spore Heat Resistance in Guava Juice and Its Control by $\mathrm{pH}$ and Sodium Benzoate
}

\author{
Evelyn $(\mathbb{D})$ and Chairul $\mathbb{D}$ \\ Department of Chemical Engineering, University of Riau, Pekanbaru 28293, Indonesia \\ Correspondence should be addressed to Evelyn; evelyn@eng.unri.ac.id
}

Received 25 February 2021; Accepted 26 May 2021; Published 16 June 2021

Academic Editor: Zheng-Fei Yan

Copyright ( 2021 Evelyn and Chairul. This is an open access article distributed under the Creative Commons Attribution License, which permits unrestricted use, distribution, and reproduction in any medium, provided the original work is properly cited.

\begin{abstract}
Heat-resistant bacteria and molds can survive the pasteurization conditions used in high-acid fruit juices. The objective of this study was to evaluate the log reductions and thermal inactivation kinetics of spores of Bacillus subtilis bacteria and ascospores of Talaromyces flavus and Eupenicillium javanicum molds under influence of $\mathrm{pH}$ and sodium benzoate preservative. The spores were suspended in guava juice, processed at $90-100^{\circ} \mathrm{C}$ for B. subtilis and at $80-90^{\circ} \mathrm{C}$ for T. flavus and E. javanicum, and decimal reduction $(D)$ values were estimated from the log survivor curves. Next, the effects of $\mathrm{pH}$ change (3.5-4.5) and $0.015 \%$ sodium benzoate addition on the $D$ values of spores were investigated. Lower $D$ values were obtained at higher temperatures $\left(D_{100 \circ \mathrm{C}}\right.$ value of $2.32 \mathrm{~min}$ vs. $D_{90 \circ \mathrm{C}}$ value of $15.33 \mathrm{~min}$ for B. subtilis, $D_{90 \circ \mathrm{C}}$ value of $2.96 \mathrm{~min}$ vs. $D_{80 \circ \mathrm{C}}$ value of $59.52 \mathrm{~min}$ for T. flavus, and $D_{90 \circ \mathrm{C}}$ value of $1.58 \mathrm{~min}$ vs. $D_{80 \circ \mathrm{C}}$ value of $21.32 \mathrm{~min}$ for $E$. javanicum). The $D$ values decreased further (to $1.8 \mathrm{~min}$ at $100^{\circ} \mathrm{C}$ for B. subtilis, to $2.33 \mathrm{~min}$ at $90^{\circ} \mathrm{C}$ for T. flavus, and to $1.49 \mathrm{~min}$ at $90^{\circ} \mathrm{C}$ for E. javanicum) when the $\mathrm{pH}$ of guava juice was decreased from 4.1 to 3.5 . Inclusion of sodium benzoate in $\mathrm{pH} 3.5$ juice enhanced the thermal inactivation of spores $\left(D_{100 \circ \mathrm{C}}\right.$ value decreased to $1.4 \mathrm{~min}$ for B. subtilis, to $1.98 \mathrm{~min}$ for $T$. flavus, and to $1.34 \mathrm{~min}$ for E. javanicum). To conclude, the combination of low $\mathrm{pH}$ and sodium benzoate provided the best method for spore inactivation, which could enhance food safety and extend food's shelf life.
\end{abstract}

\section{Introduction}

Talaromyces sp. and Eupenicillium sp. have been listed as heat-resistant molds due to their ability to form ascospores. Both molds are widely distributed in the soil, making fruit products susceptible to these mold contaminations. Ascospore germination and growth in fruit products after pasteurization reaching commonly $10^{5}-10^{6} / \mathrm{g}$ or $\mathrm{mL}$ in number are a concern since it can cause food spoilage and in some cases foodborne diseases. Decimal reduction values ( $D$ values) at $91^{\circ} \mathrm{C}$ between $0.9 \mathrm{~min}$ in strawberry pulp and $2.9 \mathrm{~min}$ in grape juice have been reported for Talaromyces sp. ascospores $[1,2]$. With respect to Eupenicillium sp. ascospores, previous studies have shown that the $D$ values in strawberry pulp and pineapple juice were 15-19.8 $\mathrm{min}, 3.7-5.0 \mathrm{~min}$, and $0.8-1.5 \mathrm{~min}$ at $80^{\circ} \mathrm{C}, 85^{\circ} \mathrm{C}$, and $90^{\circ} \mathrm{C}$, respectively $[1,3]$. Bacillus sp., such as Bacillus subtilis, is also one of the predominant microbes from bacterial genera found in soil and may also be introduced into the manufacturing process through poorly washed fruits. B. subtilis is one of the most heatresistant bacteria, resembling $D_{950 \mathrm{C}}$ value of $15.8 \mathrm{~min}$ and $D_{100 \circ \mathrm{C}}$ value of $5.7 \mathrm{~min}$ in tomato juice [4]. Our recent results for this bacterium showed the $D$ value of $6.75 \mathrm{~min}$ at $95^{\circ} \mathrm{C}$ and $2.11 \mathrm{~min}$ at $100^{\circ} \mathrm{C}$ in pineapple juice [5]. No other reports were reported for this bacterium spores in high-acid foods.

Some tropical countries are rich in the production of exotic fruits such as mango, orange, pineapple, guava, durian, and avocado. The abundant production and high nutritional contents of these fruits have made them processed into various juice blends. Guava (Psidium guava L.) is one of the very appreciated and preferred consumed juices due to its unique banana-like aroma and delicate flavour. Contamination and isolation of molds such as Talaromyces flavus and Eupenicillium javanicum and bacteria such as Bacillus subtilis in juices have been reported in past literatures [6-10]. Thus, a proper preservation method should be attempted to avoid significant economic losses and maintain food safety as well as sensorial and quality. 
Various types of preservatives have been investigated in past studies to investigate its effect on the sensitivity of microorganisms in food products and to extend food's shelf life. The preservatives reported were sorbic acid, benzoic acid, potassium sorbate, and sodium sulfite or nitrite [11], in which some of them have often been used in the food industry. Several factors such as $\mathrm{pH}$ and composition of the food product and the type of microorganism determine the inhibitory effect of the preservatives. Benzoic acid in the form of sodium benzoate is an antibacterial and antifungal agent and is widely used to preserve margarine, fresh juices, and sweets in the food industry. Common ranges of sodium benzoate used in foods are between $0.01 \%$ and $0.1 \%$ [10], with a limit of up to $0.5 \%$ were reported by European Commission [12].

Thermal processing is still the most widely applied technology in the food industry to preserve juices and beverages through inactivation of microorganisms. Typical juice processing temperatures of $95^{\circ} \mathrm{C}$ for $2 \mathrm{~min}$ may not sufficiently reduce the spores of heat-resistant microorganisms leading to juice spoilage. Determining suitable conditions to process a certain juice contaminated by certain microorganisms and investigating the potential enhancement of heat in combination with other preservation factors, among them antimicrobials, are necessary. Therefore, due to the importance of $T$. flavus and $E$. javanicum molds and B. subtilis bacteria in fruit juices, the objectives of this study were to investigate the heat, $\mathrm{pH}$, and sodium benzoate sensitivity of these bacterial and mold spores in guava juice, followed by the determination of the first-order kinetic parameters of these bacterial and mold spores in guava juice after the thermal inactivation.

\section{Materials and Methods}

2.1. Heat-Resistant Molds and Bacteria. Talaromyces flavus InaCC F155, Eupenicillium javanicum InaCC F154, and Bacillus subtilis B1204 were purchased from Indonesian Culture Collection (InaCC). Both molds were sourced from Indonesian soil, whereas B. subtilis was isolated from Curcuma zedoaria (stem). All microorganisms were revived according to the suppliers' instructions.

2.2. Spore Production. Ascospores of T. flavus and E. javanicum were obtained according to previous methods $[13,14]$. Briefly, the spore formation for both molds was confirmed after growth for four weeks at $30^{\circ} \mathrm{C}$ for periods of 30 days on potato dextrose agar (PDA), whereas the spore formation for B. subtilis was confirmed after incubation at $37^{\circ} \mathrm{C}$ for 14 days on nutrient agar. The final spore suspension was then stored at $2^{\circ} \mathrm{C}$ in SDW.

2.3. Guava Juice Preparation and Inoculation. Commercial guava juices were obtained from a local supermarket. The juices have a soluble solid content of $11.4 \pm 0.1^{\circ} \mathrm{Brix}$ and $\mathrm{pH} 4.1 \pm 0.1$ and were used as the heating medium for T. flavus, E. javanicum, and B. subtilis spores. Aliquots (ca. $1.0 \mathrm{~mL}$ ) of mold or bacterial suspension were inoculated into $9.0 \mathrm{~mL}$ of guava juice to yield an initial spore concentration of approximately $10^{8}$ or $10^{9} \mathrm{cfu} / \mathrm{mL}$ of juice. $\mathrm{NaOH}$ and $\mathrm{HCl}$ were used to adjust the $\mathrm{pH}$ of guava juices to 3.5 and 4.5 (determined with a digital $\mathrm{pH}$ meter, Mettler Toledo, USA) since these are common range $\mathrm{pH}$ values of fruit juices. Sodium benzoate was obtained from a local supermarket and added to the $\mathrm{pH} 3.5$ juice at a concentration of $0.015 \%$ $(w / v)$ in thermal processing with sodium benzoate. For each temperature, $0.075 \mathrm{~g}$ of sodium benzoate was added into 500 $\mathrm{mL}$ of guava juice.

2.4. Thermal Processing. Thermal treatments were carried out according to previous methods $[13,14]$. For T. flavus and E. javanicum ascospores, thermal death tubes containing the inoculated guava juices were immersed in preheated thermostatic water bath at 80,85 , and $90^{\circ} \mathrm{C}$ for different time intervals (up to $50 \mathrm{~min}$ with every $5 \mathrm{~min}$ ). For B. subtilis, heating was performed at 90, 95, and $100^{\circ} \mathrm{C}$ (up to $40 \mathrm{~min}$ with every $5 \mathrm{~min}$ ). Higher temperatures were attempted for $B$. subtilis since bacteria is generally more heat resistant than molds. After thermal treatment, the tubes were immediately transferred to an ice bath until microbial enumeration. Each experiment was carried out twice.

2.5. Spore Enumeration. The spore concentration in guava juice before and after processing was determined by spread plating onto PDA for the molds and onto nutrient agar for the bacteria. Prior to plating, $1 \mathrm{~mL}$ spore samples were decimal diluted using $9 \mathrm{~mL}$ of $0.85 \%$ saline solution for molds $[13,14]$, while $9 \mathrm{~mL}$ of $0.1 \%(w / v)$ sterile buffered peptone water was used for bacteria. Each tube dilution was mixed repeatedly using a high-speed vortex mixer to yield a uniform spore suspension and plated twice. The plates for bacteria were then incubated at $37^{\circ} \mathrm{C}$ for $24-48 \mathrm{hr}$, whereas the plates for molds were incubated for 3 to 5 days until visible colonies were seen. Average colony counts were calculated and spore concentration was expressed in $\mathrm{cfu} / \mathrm{mL}$ of juice sample.

2.6. Data Model Fitting and Statistical Analysis. The spore logarithmic reductions $\left(\log N / N_{0}\right)$ after the thermal treatments were calculated and plotted using Microsoft Excel 2013 (Microsoft Inc., USA). Then, the first order $D$ and $z$ value thermal resistance parameters were estimated based on the survival curves for the mold and bacterial species $[5,14,15]$. The coefficient of determination $\left(R^{2}\right)$ was used to compare the goodness of fit of the model. $N_{0}$ is the initial or untreated ascospore population $(\mathrm{cfu} / \mathrm{mL})$, and $N$ is the number of ascospores after being exposed to a lethal (heat) treatment for a specific time $(t)$. $D$ or $D_{T}$ values are decimal reduction times, which is the time in min at a certain temperature necessary to reduce the microbial population by $90 \%$ ), whereas $z$ is temperature coefficient in ${ }^{\circ} \mathrm{C}$ which is a temperature increase that results in a 10 -fold decrease in the $D_{T}$ value [16]. The $D_{T}$ values were calculated from the reciprocal of the slope in Equation (1) and $z_{T}$ values were estimated from the negative reciprocal of the slope as in Equation (2). $D_{\text {Tref }}$ is the $D$ value at the 


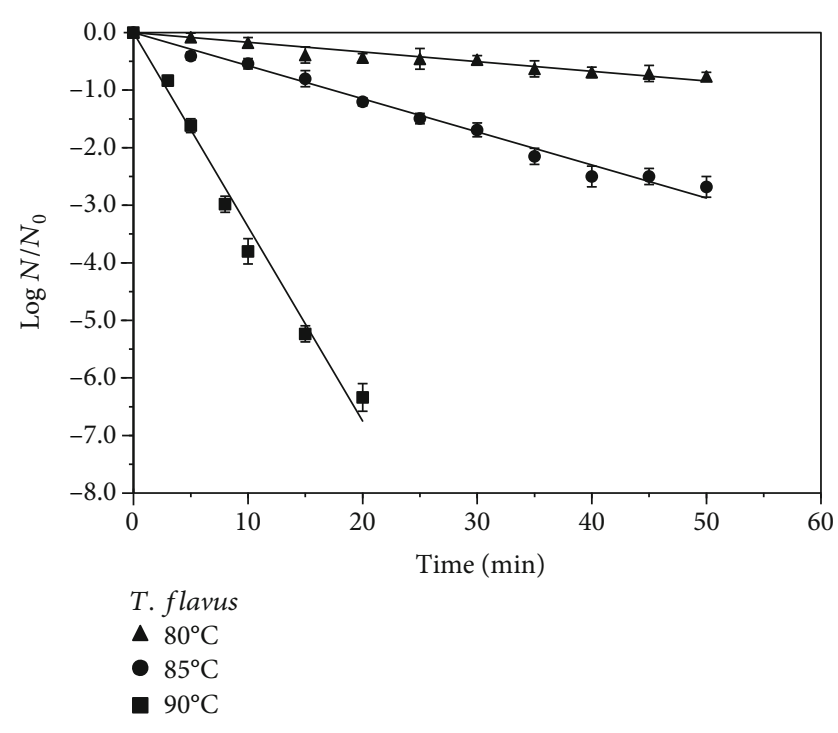

Figure 1: Heat inactivation of Talaromyces flavus ascospores in guava juice $\left(11.4^{\circ} \mathrm{Brix}, \mathrm{pH} 4.1\right)$ at $80^{\circ} \mathrm{C}-90^{\circ} \mathrm{C}$.

reference temperature or $T_{\text {ref }}$ (can be any reference temperature, ${ }^{\circ} \mathrm{C}$ ) and $T$ is the temperature of the isothermal treatment.

$$
\begin{gathered}
\log \frac{N_{(t)}}{N_{0}}=-\frac{t}{D_{T}}, \\
\log \left(\frac{D_{T}}{D_{\text {Tref }}}\right)=\left(\frac{T_{\text {ref }}-T}{z_{T}}\right) .
\end{gathered}
$$

Microsoft Excel 2013 was also used for statistical analysis of data. Single-factor ANOVA was performed to analyze synergistic effects of $\mathrm{pH}$ and sodium benzoate on the $D$ values of the same strain at $80-90^{\circ} \mathrm{C}$ using confidence level of $95 \%$.

\section{Results and Discussion}

3.1. Heat Sensitivity of Bacterial and Mold Spores in Guava Juice. The log reduction profiles of ascospores of T. flavus, E. javanicum, and B. subtilis in guava juice ( $\mathrm{pH} 4.1$ and $11.4^{\circ}$ Brix) obtained after heating at $80-90^{\circ} \mathrm{C}$ are shown in Figures 1-3. As expected, higher log reductions of the spores were obtained at higher temperatures for the same processing time. For example, a $10^{\circ} \mathrm{C}$ rise in the temperature from $80^{\circ} \mathrm{C}$ to $90^{\circ} \mathrm{C}$ for $20 \mathrm{~min}$ resulted in the increase of $T$. flavus inactivation in guava juice by $5.9 \mathrm{log}$. For E. javanicum, the same process for $10 \mathrm{~min}$ resulted in $6.3 \mathrm{log}$ reduction of these spores. With respect to $B$. subtilis, increasing the temperature from $90^{\circ} \mathrm{C}$ to $100^{\circ} \mathrm{C}$ for $10 \mathrm{~min}$ increased the inactivation by $3.7 \mathrm{log}$. Except for E. javanicum, we previously reported 6.5 $\log$ reduction for T. flavus and $4.6 \log$ reduction for B. subtilis in pineapple juice $[5,13]$, in which generally showed higher resistance in this study with guava juice for the same process conditions.

Based on the linear appearance of the log reduction profiles in Figures 1-3, decimal reduction time $(D)$ values were

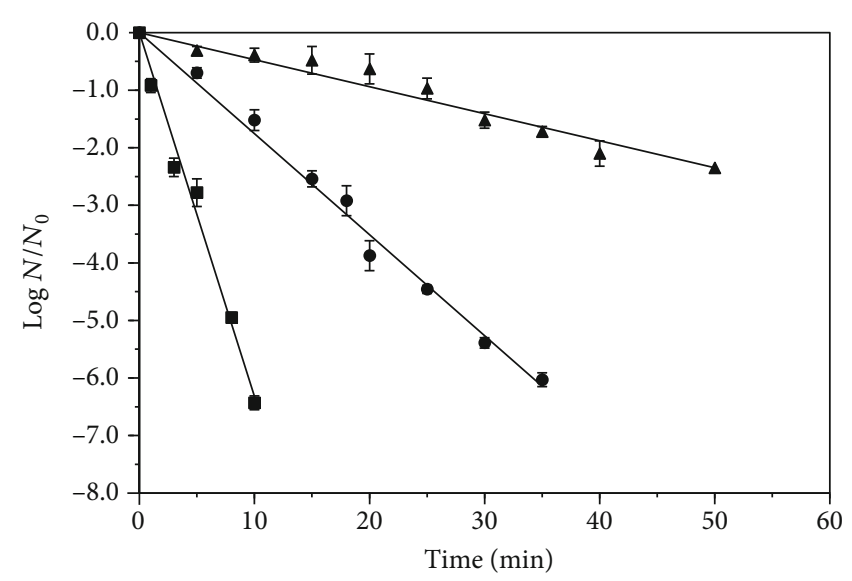

E. javanicum
- $80^{\circ} \mathrm{C}$
- $85^{\circ} \mathrm{C}$
- $90^{\circ} \mathrm{C}$

FIgURE 2: Heat inactivation of Eupenicillium javanicum ascospores in guava juice $\left(11.4^{\circ} \mathrm{Brix}, \mathrm{pH} 4.1\right)$ at $80^{\circ} \mathrm{C}-90^{\circ} \mathrm{C}$.

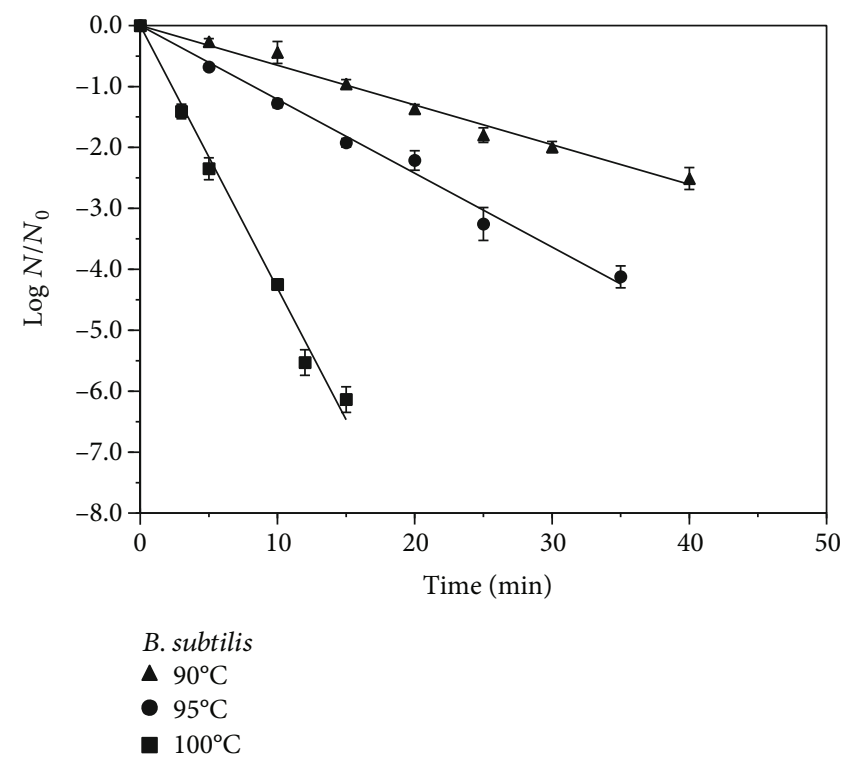

FIgURe 3: Heat inactivation of Bacillus subtilis spores in guava juice $\left(11.4^{\circ}\right.$ Brix, $\left.\mathrm{pH} 4.1\right)$ at $90^{\circ} \mathrm{C}-100^{\circ} \mathrm{C}$.

derived from the linear regressions of the best-fit straight line. The temperature changes that produced a 10-fold change in the $D$ values were also obtained and both are presented in Table 1. In general, the first-order kinetic models are supported by the $D$ value temperature dependence $\left(R^{2}=0.94-0.99\right)$. The increase in the heat sensitivity of spores with increasing temperature can be shown by lower $D$ values at higher temperatures. For $T$. flavus, the $D$ value obtained at $90^{\circ} \mathrm{C}$ was $2.96 \pm 0.06 \mathrm{~min}$ as opposed to $17.39 \pm$ $0.75 \mathrm{~min}$ at $85^{\circ} \mathrm{C}$ and $59.52 \pm 1.24 \mathrm{~min}$ at $80^{\circ} \mathrm{C}$. Regarding E. javanicum, the $D$ value found was $1.58 \pm 0.04 \mathrm{~min}$ at $90^{\circ} \mathrm{C}$ vs. $5.70 \pm 0.17 \mathrm{~min}$ at $85^{\circ} \mathrm{C}$ and $21.32 \pm 0.90 \mathrm{~min}$ at $80^{\circ} \mathrm{C}$. B. subtilis showed higher resistance in guava juice with 
TABLE 1: Heat resistance of spores of Talaromyces flavus and Eupenicillium javanicum molds and Bacillus subtilis bacteria in guava juice (pH 4.1).

\begin{tabular}{lccr}
\hline Species & Temperature $\left({ }^{\circ} \mathrm{C}\right)$ & $D_{T}$ value $(\mathrm{min}) \pm \mathrm{SD}^{*}$ & $z$ value $\left({ }^{\circ} \mathrm{C}\right) \pm \mathrm{SE}$ \\
\hline Mold: & 80 & $59.52 \pm 1.24$ & $7.7 \pm 0.10$ \\
\hline T. flavus & 85 & $17.39 \pm 0.75$ & $R^{2}=0.94-0.99$ \\
\hline Mold: & 90 & $2.96 \pm 0.06$ & $8.9 \pm 0.01$ \\
\hline E. javanicum & 80 & $21.32 \pm 0.90$ & $R^{2}=0.94-0.99$ \\
\hline Bacteria: & 85 & $5.70 \pm 0.17$ & $1.58 \pm 0.04$ \\
\hline B. subtilis & 90 & $15.33 \pm 1.7$ & $12.2 \pm 0.07$ \\
\hline
\end{tabular}

${ }^{*} D$ values shown are average of two experiments \pm standard deviation.

TABLE 2: The effect of $\mathrm{pH}$ change on the heat resistance of spores of Talaromyces flavus and Eupenicillium javanicum molds and Bacillus subtilis bacteria in guava juice.

\begin{tabular}{|c|c|c|c|c|}
\hline Species & $\mathrm{pH}$ & Temperature $\left({ }^{\circ} \mathrm{C}\right)$ & $D_{T}$ value $(\min ) \pm \mathrm{SD}^{*}$ & $z$ value $\left({ }^{\circ} \mathrm{C}\right) \pm \mathrm{SE}$ \\
\hline Mold: & 3.5 & 80 & $48.21 \pm 1.15$ & $7.6 \pm 0.14$ \\
\hline \multirow{5}{*}{ T. flavus } & \multirow{5}{*}{4.5} & 85 & $15.82 \pm 0.52$ & \multirow[t]{2}{*}{$R^{2}=0.94-0.99$} \\
\hline & & 90 & $2.33 \pm 0.02$ & \\
\hline & & 80 & $71.42 \pm 1.69$ & $7.2 \pm 0.23$ \\
\hline & & 85 & $27.59 \pm 1.10$ & \multirow[t]{2}{*}{$R^{2}=0.93-0.98$} \\
\hline & & 90 & $2.86 \pm 0.05$ & \\
\hline \multirow[t]{3}{*}{ Mold: } & 3.5 & 80 & $17.70 \pm 0.65$ & $9.3 \pm 0.01$ \\
\hline & & 85 & $5.13 \pm 0.12$ & \multirow{2}{*}{$R^{2}=0.96-0.99$} \\
\hline & & 90 & $1.49 \pm 0.04$ & \\
\hline \multirow[t]{3}{*}{ E. javanicum } & 4.5 & 80 & $26.65 \pm 0.94$ & \multirow{3}{*}{$\begin{array}{c}8.3 \pm 0.08 \\
R^{2}=0.96-0.99\end{array}$} \\
\hline & & 85 & $8.35 \pm 0.22$ & \\
\hline & & 90 & $1.68 \pm 0.03$ & \\
\hline \multirow[t]{3}{*}{ Bacteria: } & 3.5 & 90 & $11.2 \pm 0.23$ & $12.6 \pm 0.12$ \\
\hline & & 95 & $6.3 \pm 0.11$ & \multirow[t]{2}{*}{$R^{2}=0.94-0.99$} \\
\hline & & 100 & $1.8 \pm 0.02$ & \\
\hline \multirow[t]{3}{*}{ B. subtilis } & 4.5 & 90 & $17.9 \pm 0.42$ & \multirow{3}{*}{$\begin{array}{c}11.7 \pm 0.18 \\
R^{2}=0.93-0.98\end{array}$} \\
\hline & & 95 & $10.2 \pm 0.16$ & \\
\hline & & 100 & $2.5 \pm 0.01$ & \\
\hline
\end{tabular}

${ }^{*} D$ values shown are average of two experiments \pm standard deviation.

the $D$ values obtained being $15.33 \pm 1.7 \mathrm{~min}, 8.25 \pm 0.9 \mathrm{~min}$, and $2.32 \pm 0.7 \mathrm{~min}$ at $90^{\circ} \mathrm{C}, 95^{\circ} \mathrm{C}$, and $100^{\circ} \mathrm{C}$, respectively, as bacteria commonly exhibit higher resistance than mold or yeast spores. Past studies showed the $D_{90 \circ \mathrm{C}}$ values of these bacteria and mold spores in pineapple juices which were slightly lower than reported in this study, i.e., $2.89 \mathrm{~min}$ for T. flavus [13], $1.45 \mathrm{~min}$ for E. javanicum [3], and $13.2 \mathrm{~min}$ for B. subtilis [4], confirming the food matrix effect. Nonetheless, the obtained $D_{90 \circ \mathrm{C}}$ values are still in the common range reported values in various juices for these molds and bacteria in past studies (1.13-7.5 min) [1, 3, 13, 17-19]. It has been known that differences in the $D$ values of bacterial and mold spores are not only affected by strain but also by many other factors such as the composition of fruit products and medium or sporulation conditions prior to heat treatment. The $z$ values estimated in this case were between $7.7^{\circ} \mathrm{C}$ and $8.9^{\circ} \mathrm{C}$ for molds and $12.2^{\circ} \mathrm{C}$ for $B$. subtilis (Table 1 ), which are within the expected values for these microorganisms. 
TABLE 3: Heat resistance of spores of Talaromyces flavus and Eupenicillium javanicum in guava juice (pH 3.5) treated with $0.015 \%$ sodium benzoate.

\begin{tabular}{lccr}
\hline Species & Temperature $\left({ }^{\circ} \mathrm{C}\right)$ & $D_{T}$ value $(\mathrm{min}) \pm \mathrm{SD}^{*}$ & $z$ value $\left({ }^{\circ} \mathrm{C}\right) \pm \mathrm{SE}$ \\
\hline Mold: & 80 & $33.33 \pm 1.12$ & $8.2 \pm 0.05$ \\
\hline T. flavus & 85 & $10.43 \pm 0.15$ & $R^{2}=0.95-0.99$ \\
\hline Mold: & 90 & $1.98 \pm 0.04$ & $10.2 \pm 0.05$ \\
\hline E. javanicum & 80 & $12.80 \pm 0.60$ & $R^{2}=0.95-0.99$ \\
\hline Bacteria: & 85 & $3.59 \pm 0.03$ & $1.34 \pm 0.01$ \\
\hline B. subtilis & 90 & $10.9 \pm 0.33$ & $1.2 \pm 0.13$ \\
\hline
\end{tabular}

${ }^{*} D$ values shown are average of two experiments \pm standard deviation.

The $z$ values also reflected the heat resistance of microbes, being higher for the bacteria than for the molds. To conclude, $95^{\circ} \mathrm{C}-2 \mathrm{~min}$ of fruit juice processing would remove the spores of E. javanicum; however, it is not suitable for a 5-log reduction of T. flavus and B. subtilis spores.

3.2. $p H$ Sensitivity of Bacterial and Mold Spores in Guava Juice. Table 2 shows the effect of $\mathrm{pH}$ change on the decimal reduction $(D)$ values of spores of $T$. flavus and E. javanicum molds and $B$. subtilis bacteria in guava juices adjusted to $\mathrm{pH}$ 3.5 and 4.5. Generally, the microorganisms tend to show greater heat sensitivity at lower juice's $\mathrm{pH}$ resulting in lower $D$ values. For T. flavus in $\mathrm{pH} 3.5$ juice, the $D_{T}$ values obtained to inactivate $1-\log$ of spores were $48.21 \pm 1.15 \mathrm{~min}$ at $80^{\circ} \mathrm{C}$, $15.82 \pm 0.52 \mathrm{~min}$ at $85^{\circ} \mathrm{C}$, and $2.33 \pm 0.02 \mathrm{~min}$ at $90^{\circ} \mathrm{C}$. Meanwhile, in $\mathrm{pH} 4.5$ juice, the $D_{T}$ values found to inactivate 1-log of spores were $71.42 \pm 1.69 \mathrm{~min}$ at $80^{\circ} \mathrm{C}, 27.59 \pm 1.10 \mathrm{~min}$ at $85^{\circ} \mathrm{C}$, and $2.86 \pm 0.05 \mathrm{~min}$ at $90^{\circ} \mathrm{C}$. For E. javanicum in $\mathrm{pH}$ 3.5 juice, the $D_{T}$ values found for 1-log of spores were $17.70 \pm 0.65 \mathrm{~min}$ at $80^{\circ} \mathrm{C}, 5.13 \pm 0.12 \mathrm{~min}$ at $85^{\circ} \mathrm{C}$ and 1.49 $\pm 0.04 \mathrm{~min}$ at $90^{\circ} \mathrm{C}$. Meanwhile, for $\mathrm{pH} 4.5$, the $D_{\mathrm{T}}$ values found $1-\log$ of spores were $26.65 \pm 0.94 \mathrm{~min}$ at $80^{\circ} \mathrm{C}, 8.35 \pm$ $0.22 \mathrm{~min}$ at $85^{\circ} \mathrm{C}$, and $1.68 \pm 0.03 \mathrm{~min}$ at $90^{\circ} \mathrm{C}$. The greater sensitivity of microorganisms in lower $\mathrm{pH}$ juices was also confirmed for B. subtilis. For example, the $D_{90 \circ \mathrm{C}}$ values of $11.2 \pm 0.23 \mathrm{~min}$ vs. $17.9 \pm 0.42 \mathrm{~min}$ were obtained at $\mathrm{pH} 3.5$ and $\mathrm{pH} 4.5$, respectively. In addition, the $D_{100 \circ \mathrm{C}}$ value of 1.8 \pm 0.02 min was obtained at $\mathrm{pH} 3.5$ and the $D_{100 \circ \mathrm{C}}$ value of $2.5 \pm 0.01 \mathrm{~min}$ was obtained at $\mathrm{pH} 4.5$, although the differences were small. Past studies have shown that the heat resistance of spores of bacteria from Bacillus and Clostridium genera increased with increasing $\mathrm{pH}$ values and displayed maximum values at $\mathrm{pH}$ close to neutrality [20-22]. Similar observations of decreasing sensitivity of spores with $\mathrm{pH}$ values have also been observed by other investigators with Aspergillus flavus and Penicillium digitatum mold spores ( $\mathrm{pH} 3.0$ to 5.5) and Alicyclobacillus acidoterrestris spores (pH 2.5 to 6.0$)[23,24]$. Although the $z$ values were slightly lower in higher $\mathrm{pH}$ juices for all microorganisms, these observations were in agreement with the results of $A$. acido-

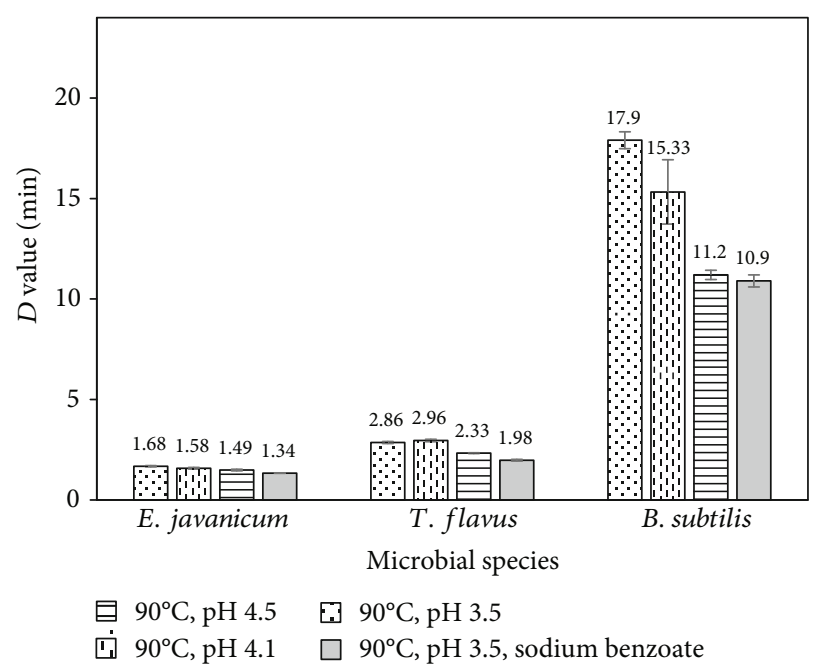

FIgure 4: Comparison of decimal reduction values of Bacillus subtilis bacteria and Talaromyces flavus and Eupenicillium javanicum molds in $11.4^{\circ}$ Brix guava juice at $90^{\circ} \mathrm{C}$ (values are average \pm standard deviation).

terrestris spore thermal inactivation in grapefruit juices with $\mathrm{pH}$ change from 3.0 to 4.0 [25].

3.3. Sodium Benzoate Sensitivity of Bacterial and Mold Spores in Guava Juice. Sensitivity of T. flavus and E. javanicum molds and B. subtilis bacteria to sodium benzoate indicated by the decimal reduction $(D)$ values in guava juice at $\mathrm{pH} 3.5$ was studied, and the results are presented in Table 3. Generally, the molds exhibited greater heat sensitivity than the bacterial spores. As can be seen from Table 3, the addition of $0.015 \%$ sodium benzoate caused further decreases in the $D$ values of all tested microbial spores in guava juices, with a maximum reduction value of around 30\% being observed for $T$. flavus. The $D_{T}$ values obtained for $T$. flavus were $33.33 \pm 1.12 \mathrm{~min}$ at $80^{\circ} \mathrm{C}, 10.43 \pm 0.15 \mathrm{~min}$ at $85^{\circ} \mathrm{C}$, and 1.98 $\pm 0.04 \mathrm{~min}$ at $90^{\circ} \mathrm{C}$. Meanwhile, for E. javanicum, the $D_{T}$ values achieved were $12.80 \pm 0.60 \mathrm{~min}$ at $80^{\circ} \mathrm{C}, 3.59 \pm 0.03$ $\min$ at $85^{\circ} \mathrm{C}$, and $1.34 \pm 0.01 \mathrm{~min}$ at $90^{\circ} \mathrm{C}$. With respect to 
B. subtilis, the $D$ values found were $10.9 \pm 0.33 \mathrm{~min}, 5.2 \pm$ $0.05 \mathrm{~min}$, and $1.4 \pm 0.02 \mathrm{~min}$ at $80^{\circ} \mathrm{C}, 85^{\circ} \mathrm{C}$, and $90^{\circ} \mathrm{C}$, respectively.

Bar charts for the $D$ values between 80 and $90^{\circ} \mathrm{C}$ were further constructed, and the results at $90^{\circ} \mathrm{C}$ are presented in Figure 4 . Then, statistical analysis was carried out to compare the difference in the $D$ values. Analysis results showed that there were significant differences in the $D$ values of the same strain after all treatments $(p<0.05)$ and more prone at lower temperatures, suggesting a synergistic effect between low $\mathrm{pH}$ and sodium benzoate to reduce the heat resistance of these microorganisms. The inactivation effect of heat combined pH3.5-sodium benzoate was better than the inactivation effect of heating at pH3.5 alone or higher $\mathrm{pHs}$, i.e., $\mathrm{pH} 4.1$ and 4.5. According to Restaino et al. [26], lowering $\mathrm{pH}$ of the medium and increasing the concentration or addition of preservatives would inhibit the growth and activity of microorganisms. However, the effectiveness of sodium benzoate to sensitize microorganisms decreased at higher $\mathrm{pH}$, which is in agreement with other studies [27]. Reductions in the $D$ values of several molds (B. nivea, Aspergillus flavus, Penicillium puberulum, and Geotrichum candidum) after addition of $1000 \mu \mathrm{g} / \mathrm{mL}$ of sodium benzoate have been observed in past studies [28]. Inhibitory effects of sodium benzoate on heat-damaged Bacillus stearothermophilus spores have also been reported by other authors [29]; however, to the best of our knowledge, the heat sensitization of spores of B. subtilis by sodium benzoate was first reported in this study. Nevertheless, the effectiveness of chemical preservatives is often limited by their actions or adverse effects in food products [30].

\section{Conclusion}

Bacillus subtilis had higher heat resistibility in the guava juice compared to the molds (Talaromyces flavus and Eupenicillium javanicum). The spores of B. subtilis decreased by 5 $\log$ cycles within $11.6 \mathrm{~min}$ at $100^{\circ} \mathrm{C}$ whereas $3.61 \mathrm{~min}$ were required for $\mathrm{T}$. flavus at $95^{\circ} \mathrm{C}$, which exceeds the typical juice processing conditions. The logarithmic values of surviving spores of these microorganisms in the juice followed the first-order kinetic model with coefficient determinations of more than 0.93 . Lowering the $\mathrm{pH}$ of the juice and inclusion of $0.015 \%$ sodium benzoate in the juice prior to heating increased the bacteria and molds' heat sensitivity and thus decreased the resistance to pasteurization.

\section{Data Availability}

All the data relevant to the research can be found in the manuscript. Any further information is available from the corresponding author upon request.

\section{Conflicts of Interest}

The authors declare no conflict of interest.

\section{Acknowledgments}

This work was supported by the laboratory staff at Chemical Engineering Department, University of Riau, Indonesia. We would like to express our deep gratitude to Directorate General of Research, Technology, and Higher Education, Republic Indonesia, through Penelitian Dasar Unggulan Perguruan Tinggi (PDUPT) Research Grant No. 405/UN.19.5.1.3/PT.01.03/2020. Other research support from Tanoto Foundation No. 684/TF-JKT/IX/2020 is also appreciated.

\section{References}

[1] G. M. F. Aragão, Identificação e determinação da resistência térmica de fungos filamentosos termorresistentes isolados da polpa de morango, [Ph.D. thesis], Universidade de Campinas, Campinas-Brazil, 1989.

[2] S. Quintavalla and E. Spotti, "Heat resistance of Talaromyces flavus, Neosartorya fischeri and Byssochlamys nivea isolated from fresh fruits," Microbiologie Aliments Nutrition, vol. 11, pp. 335-341, 1993.

[3] Evelyn, Chairul, S. R. Muria, L. Adella, and R. Ramadhani, "Thermal inactivation of Eupenicillium javanicum ascospores in pineapple juice: effect of temperature, soluble solids and spore age," Journal of Physics: Conference Series, vol. 1655, pp. 1-8, 2020.

[4] J. H. Rodriguez, M. A. Cousin, and P. E. Nelson, "Thermal resistance and growth of Bacillus licheniformis and Bacillus subtilis in tomato juice," Journal of Food Protection, vol. 56, no. 2, pp. 165-168, 1993.

[5] Evelyn, S. P. Utami, and Chairul, "Effect of temperature and soluble solid onBacillus subtilis and Bacillus licheniformis spore inactivation and quality degradation of pineapple juice," Food Science and Technology International, 2021.

[6] D. A. King Jr. and W. U. Halbrook, "Ascospore heat resistance and control measures for Talaromyces flaws isolated from fruit juice concentrate," Journal of Food Science, vol. 52, no. 5, pp. 1252-1254, 1987.

[7] Y. Ma, X. Hu, J. Chen, G. Zhao, and X. Liao, "Effect of UHP on enzyme, microorganism and flavor in cantaloupe (Cucumis melo L.) juice," Journal of Food Process Engineering, vol. 33, pp. 540-553, 2010.

[8] J. O. Mundt, J. L. Collins, I. E. McCarty, and R. Bailey, "Description and microbiology of home-canned tomatoes and tomato juice," Journal of Food Protection, vol. 41, no. 12, pp. 944-947, 1978.

[9] J. I. Pitt and A. D. Hocking, Fungi and Food Spoilage, Springer Science and Business Media, New York, 2009.

[10] V. Tournas, "Heat-resistant fungi of importance to the food and beverage industry," Critical Reviews in Microbiology, vol. 20, no. 4, pp. 243-263, 1994.

[11] R. García-García and S. S. Searle, Encyclopedia of Food and Health, Academic Press, 2016.

[12] European Commission, European Union Directive 95/2/CE from 20.02.1995 on food additives, colorants and sweeteners, European Commission, 1995.

[13] Evelyn, S. R. Muria, Chairul, D. Fozla, and F. K. Khoirunnisa, "Thermal inactivation of Talaromyces flavus ascospores in pineapple juice as influenced by temperature, soluble solids, and 
spore age," Journal of Advanced Research in Fluid Mechanics and Thermal Sciences, vol. 69, no. 2, pp. 111-119, 2020.

[14] Evelyn and F. V. M. Silva, "Inactivation of Byssochlamys nivea ascospores in strawberry puree by high pressure, power ultrasound and thermal processing," International Journal of Food Microbiology, vol. 214, pp. 129-136, 2015.

[15] Evelyn, H. J. Kim, and F. V. M. Silva, "Modeling the inactivation of Neosartorya fischeri ascospores in apple juice by high pressure, power ultrasound and thermal processing," Food Control, vol. 59, pp. 530-537, 2016.

[16] W. D. Bigelow and J. Esty, "The thermal death point in relation to time of typical thermophilic organisms," Journal of Infectious Diseases, vol. 27, pp. 602-617, 1921.

[17] L. R. Beuchat, "Thermal tolerance of Talaromyces flavus ascospores as affected by growth medium and temperature, age and sugar content in the inactivation medium," Transactions of the British Mycological Society, vol. 90, no. 3, pp. 359-364, 1988.

[18] V. N. Scott and D. T. Bernard, "Heat resistance of Talaromyces flavus and Neosartorya fischeri isolated from commercial fruit juices," Journal of Food Protection, vol. 50, no. 1, pp. 18-20, 1987.

[19] J. E. Vander Spuy, F. N. Matthee, and D. J. A. Crafford, “The heat resistance of moulds Penicillium vermiculatum dangeard and Penicillium brefeldianum dodge in apple juice," Phytophylactica, vol. 7, pp. 105-108, 1975.

[20] M. S. Cameron, S. J. Leonard, and E. L. Barret, "Effect of moderately acidic $\mathrm{pH}$ on heat resistance of Clostridium sporogenes spores in phosphate buffer and in buffered pea puree," Applied and Environmental Microbiology, vol. 39, no. 5, pp. 943-949, 1980.

[21] A. Fernandez, M. J. Ocio, P. S. Fernandez, M. Rodrigo, and A. Martinez, "Application of nonlinear regression analysis to the estimation of kinetic parameters for two enterotoxigenic strains of Bacillus cereus spores," Food Microbiology, vol. 16, no. 6, pp. 607-613, 1999.

[22] H. Xezones and I. S. Hutchings, "Thermal resistance of Clostridium botulinum (62 A) spores as affected by fundamental food constituents," Food Technology, vol. 19, no. 6, pp. 113116, 1965.

[23] A. López-Malo, E. Palou, M. Jiménez-Fernández, S. M. Alzamora, and S. Guerrero, "Multifactorial fungal inactivation combining thermosonication and antimicrobials," Journal of Food Engineering, vol. 67, no. 1-2, pp. 87-93, 2005.

[24] F. V. M. Silva, P. A. Gibbs, M. C. Vieira, and C. L. M. Silva, "Thermal inactivation of Alicyclobacillus acidoterrestris spores under different temperature, soluble solids and $\mathrm{pH}$ conditions for the design of fruit processes," International Journal of Food Microbiology, vol. 51, no. 2-3, pp. 95-103, 1999.

[25] E. Kamitopoulou, I. S. Boziaris, E. A. Davies, J. DelvesBroughton, and M. R. Adams, "Alicyclobacillus acidoterrestris in fruit juices and its control by nisin," International Journal of Food Science and Technology, vol. 34, no. 1, pp. 81-85, 1999.

[26] L. Reistano, K. K. Komatsu, and M. J. Syracuse, "Effects of acids on potassium sorbate inhibition of food-related microorganisms in culture media," Journal of Food Science, vol. 47, no. 1, pp. 134-143, 1981.

[27] I. J. Salma, M. A. Sajib, M. Motalab et al., "Comparative evaluation of macro and micro-nutrient element and heavy metal contents of commercial fruit juices available in Bangladesh," American Journal of Food and Nutrition, vol. 3, no. 2, pp. 56-63, 2015.
[28] L. R. Beuchat, "Combined effects of solutes and food preservatives on rates of inactivation of and colony formation by heated spores and vegetative cells of molds," Applied and Environmental Microbiology, vol. 41, no. 2, pp. 472-477, 1981.

[29] M. Lopez, S. Martinez, J. Gonzalez, R. Martin, and A. Bernardo, "Sensitization of thermally injured spores of Bacillus stearothermophilus to sodium benzoate and potassium sorbate," Letters in Applied Microbiology, vol. 27, no. 6, pp. 331-335, 1998.

[30] M. Shahmihammadi, M. Javadi, and M. Nassiri-Asl, "An overview on the effects of sodium benzoate as a preservative in food products," Biotechnology, Health and Sciences, vol. 3, no. 3, article 35084, 2016. 